\title{
REAKTUALISASI MOTIF BATIK PADA ELEMEN DESAIN INTERIOR BERBASIS TEKNOLOGI
}

\author{
Ida Bagus Ananta Wijaya* \\ Jurusan Desain Interior, Institut Teknologi Kreatif Binus Malang
}

\begin{abstract}
ABSTRAK
Perkembangan teknologi dan seni tradisi merupakan jangka waktu yang terbalik. Teknologi berfikir jauh ke depan, sedangkan seni tradisi berfikir jauh ke belakang. Hal inilah salah satu penyebab seni tradisi mulai hilang di era milenial ini. Dalam dunia desain interior, beberapa hasil seni tradisi misalnya motif batik khas nusantara sangat jarang diaplikasikan pada elemen desain interior. Tujuan dari penelitian ini adalah untuk mengetahui bagaimana aplikasi teknologi dapat digunakan untuk mempertahankan motif batik pada elemen interior seperti lantai, dinding, plafon maupun perabot dalam interior. Metodologi yang digunakan dalam penelitian ini adalah metode kualitatif. Hasil yang didapatkan dari penelitian ini diharapkan dapat membantu desainer interior untuk mengetahui bagaimana aplikasi motif batik pada elemen interior melalui material yang digunakan, teknologi dan software yang mendukungnya. Sehingga dengan adanya aplikasi motif batik pada elemen interior, re-aktualisasi motif batik dapat terjadi seiring perkembangan jaman dan teknologi. Kesimpulan yang didapatkan dari penelitian ini adalah motif batik dapat diaplikasikan pada elemen desain interior sejalan dengan adanya perkembangan teknologi.
\end{abstract}

Kata kunci: reaktualisasi, batik, teknologi, material, interior.

\section{PENDAHULUAN}

Perkembangan teknologi dan seni tradisi merupakan jangka waktu yang terbalik. Teknologi berpikir jauh ke depan, selalu ada inovasi dan hal yang baru setiap saat. Inovasi ini dapat berupa inovasi bahan dan material, metode perencanaan dan pelaksanaan, serta inovasi dalam hal alat-alat pendukungnya. Menurut Kamus Besar Bahasa Indonesia (KBBI), teknologi adalah metode ilmiah untuk mencapai tujuan praktis, ilmu pengetahuan terapan. Dengan kata lain, teknologi akan terus berkembang untuk membuat segalanya lebih praktis.

Dalam dunia interior, perkembangan teknologi juga berkembang sangat pesat. Perkembangan dalam dunia industri interior dimulai dari perkembangan gaya interior. Dari gaya interior menuntut adanya teknologi yang mendukung perkembangan ini, misalnya material dan teknik pelaksanaan atau teknik produksinya.

Berbeda dengan teknologi yang selalu berkembang dan berfikir ke era masa depan, seni tradisi akan tetap tak berubah dan berfikir jauh ke belakang/masa lampau. Seiring dengan berjalannya waktu, seni tradisi dalam dunia interior mulai ditinggalkan atau dilupakan karena dianggap kuno, tidak menarik atau tidak serasi dengan perkembangan gaya interior saat ini. Hal inilah beberapa penyebab seni tradisi tidak dimasukkan dalam elemen desain interior.

Dalam dunia desain interior, beberapa hasil seni tradisi misalnya motif batik khas nusantara sangat jarang diaplikasikan pada elemen desain interior. Padahal motif batik ini akan sangat menarik jika diaplikasikan pada elemen pembentuk interior misalnya dinding pembatas. Menurut Wulandari (2011) Batik, adalah wujud hasil cipta karya seni yang adiluhung, diekspresikan pada motif kain untuk pakaian, sarung, kain panjang, dan kain dekoratif lainnya. Kemudian berkembang menjadi lukisan batik, sepatu hingga patung kayu. Batik tulis, dibuat dengan menggunakan malam dan canting. Awal pengenalan batik di Indonesia melalui proses asimilasi kebudayaan pendatang Cina dan India, kemudian dengan penduduk pribumi. Sejalan dengan perkembangan nilai sosial dan budaya bangsa Indonesia, batik hasil karya seni tumbuh dan berkembang menjadi kekayaan nasional yang bernilai tinggi.

Agar dapat sejalan dengan perkembangan gaya interior yag ada, maka perlu adanya Reaktualisasi. Menurut Kamus Besar Bahasa Indonesia (KBBI), Re-aktualisasi adalah proses, cara, perbuatan mengaktualisasikan kembali; penyegaran dan pembaruan nilai-nilai kehidupan 
masyarakat. Dalam konteks penelitian ini, re-aktualisasi yang dimaksud adalah penyegaran atau pembaruan motif batik sejalan dengan perkembangan teknologi, berupa penggunaan material serta teknik pembuatannya.

\section{TINJAUAN BATIK}

Di Indonesia, sejarah batik berkaitan erat dengan perkembangan kerajaan Majapahit serta penyebaran ajaran Islam di Tanah Jawa. Sejak zaman kerjaan Majapahit dan terus berkembang kepada kerajaan dan raja-raja berikutnya, kesenian batik ini menjadi milik rakyat Indonesia dan khususnya suku Jawa ialah setelah akhir abad ke-XVIII atau awal abad ke-XIX. Batik yang dihasilkan ialah semuanya batik tulis sampai awal abad ke-XX dan batik cap dikenal baru setelah perang dunia kesatu habis atau sekitar tahun 1920. Adapun kaitan dengan penyebaran ajaran Islam. Banyak daerah-daerah pusat perbatikan di Jawa adalah daerah-daerah santri dan kemudian Batik menjadi alat perjaungan ekonomi oleh tokoh-tokoh pedangan Muslim melawan perekonomian Belanda.

\section{Jaman Majapahit}

Batik yang telah menjadi kebudayaan di kerajaan Majapahit, dapat ditelusuri di daerah Mojokerto dan Tulung Agung. Mojoketo adalah daerah yang erat hubungannya dengan kerajaan Majapahit semasa dahulu dan asal nama Majokerto ada hubungannya dengan Majapahit. Kaitannya dengan perkembangan batik asal Majapahit berkembang di Tulung Agung adalah riwayat perkembangan pembatikan didaerah ini, dapat digali dari peninggalan di zaman kerajaan Majapahit.

Daerah pembatikan sekarang di Mojokerto terdapat di Kwali, Mojosari, Betero dan Sidomulyo. Diluar daerah Kabupaten Mojokerto ialah di Jombang. Pada akhir abad ke-XIX ada beberapa orang kerajinan batik yang dikenal di Mojokerto, bahan-bahan yang dipakai waktu itu kain putih yang ditenun sendiri dan obat-obat batik dari soga jambal, mengkudu, nila tom, tinggi dan sebagainya.

Ciri khas dari batik Kalangbret dari Mojokerto adalah hampir sama dengan batik-batik keluaran Yogyakarta, yaitu dasarnya putih dan warna coraknya coklat muda dan biru tua. Yang dikenal sejak lebih dari seabad yang lalu tempat pembatikan didesa Majan dan Simo. Desa ini juga mempunyai riwayat sebagai peninggalan dari zaman peperangan Pangeran Diponegoro tahun 1825.

\section{Jaman Penyebaran Islam}

Riwayat pembatikan di daerah Jawa Timur lainnya adalah di Ponorogo, yang kisahnya berkaitan dengan penyebaran ajaran Islam di daerah ini. Riwayat Batik. Disebutkan masalah seni batik didaerah Ponorogo erat hubungannya dengan perkembangan agama Islam dan kerajaankerajaan dahulu. Konon, di daerah Batoro Katong, ada seorang keturunan dari kerajaan Majapahit yang namanya Raden Katong adik dari Raden Patah. Batoro Katong inilah yang membawa agama Islam ke Ponorogo dan petilasan yang ada sekarang ialah sebuah mesjid didaerah Patihan Wetan.

Perkembangan selanjutanya, di Ponorogo, di daerah Tegalsari ada sebuah pesantren yang diasuh Kyai Hasan Basri atau yang dikenal dengan sebutan Kyai Agung Tegalsari. Pesantren Tegalsari ini selain mengajarkan agama Islam juga mengajarkan ilmu ketatanegaraan, ilmu perang dan kesusasteraan. Seorang murid yang terkenal dari Tegalsari dibidang sastra ialah Raden Ronggowarsito. Kyai Hasan Basri ini diambil menjadi menantu oleh raja Kraton Solo.

Waktu itu seni batik baru terbatas dalam lingkungan kraton. Oleh karena putri keraton Solo menjadi istri Kyai Hasan Basri maka dibawalah ke Tegalsari dan diikuti oleh pengiringpengiringnya, disamping itu banyak pula keluarga kraton Solo belajar dipesantren ini. Peristiwa inilah yang membawa seni bafik keluar dari kraton menuju ke Ponorogo. Pemuda-pemudi yang dididik di Tegalsari ini kalau sudah keluar, dalam masyarakat akan menyumbangkan dharma batiknya dalam bidang-bidang kepamongan dan agama.

Daerah perbatikan lama yang bisa kita lihat sekarang ialah daerah Kauman yaitu Kepatihan Wetan sekarang dan dari sini meluas ke desa-desa Ronowijoyo, Mangunsuman, Kertosari, Setono, Cokromenggalan, Kadipaten, Nologaten, Bangunsari, Cekok, Banyudono dan Ngunut. Waktu itu obat-obat yang dipakai dalam pembatikan ialah buatan dalam negeri sendiri dari kayu-kayuan antara lain; pohon tom, mengkudu, kayu tinggi. Sedangkan bahan kainputihnyajugamemakai buatan sendiri dari tenunan gendong. Kain putih import bam dikenal di Indonesia kira-kira akhir abad ke-19. 
Pembuatan batik cap di Ponorogo baru dikenal setelah perang dunia pertama yang dibawa oleh seorang Cina bernama Kwee Seng dari Banyumas. Daerah Ponorogo awal abad ke-20 terkenal batiknya dalam pewarnaan nila yang tidak luntur dan itulah sebabnya pengusaha-pengusaha batik dari Banyumas dan Solo banyak memberikan pekerjaan kepada pengusaha-pengusaha batik di Ponorogo. Akibat dikenalnya batik cap maka produksi Ponorogo setelah perang dunia petama sampai pecahnya perang dunia kedua terkenal dengan batik kasarnya yaitu batik cap mori biru. Pasaran batik cap kasar Ponorogo kemudian terkenal seluruh Indonesia.

\section{Motif Batik}

Motif batik sangat beragam di Indonesia. Setiap daerah memiliki ragam dan corak batik tersendiri. Secara umum akan dijabarkan sebagai berikut.

a. Motif Batik Sido Asih

Motif batik ini memiliki makna agar dalam berumah tangga, hidupnya selalu dipenuhi dengan kasih sayang. Maka dari itu batik sido asih kegunaannya sama dengan batik sido luhur karena dipakai pengantin wanita pada acara pernikahan. Dan jika diartikan dalam arti luas, makna dari batik sido asih adalah agar manusia saling mengasihi dan menyayangi antar sesame manusia dan makhluk hidup.

b. Motif Batik Kawung

Motif Kawung juga termasuk motif tertua yang ada di Indonesia. Motif ini sendiri adalah gambaran dari buah kawung alias buah aren. Dahulu, batik ini hanya boleh digunakan oleh orang orang kerajaan. Dan digunakan sebagai sarung raja maupun permaisuri. Motif batik ini merupakan gambaran dari buah kawung atau yang lebih di kenal sebagai buah aren. Motif salib diantara 4 oval pada motif batik ini mengacu pada sumber energi universal.

c. Motif Batik Mega Mendung

Motif ini merupakan motif batik asli dari Cirebon. Motif ini menggambarkan pola berbentuk awan awan dan berwarna gelap seperti merah tua, hijau tua, biru tua dan sebagainya. Motif satu ini berasal dari kota Cirebon serta memiliki ciri khas dalam pembuatannya.

Batik Mega Mendung akan dihiasi aneka pola berbentuk awan yang warnanya gelap seperti merah tua, biru tua, hijau tua dan lain-lain. Motif ini juga menjadi ikon dari kota Cirebon sehingga sangat khas akan daerah asalnya. Belum lengkap rasanya membawa pulang oleholeh dari Cirebon jika tidak termasuk batik Mega Mendung ini.

d. Motif Batik Sekar Jagad

Motif ini berasal dari Yogyakarta. Sesuai dengan namanya, Sekar Jagad yang memiliki arti keindahan yang membuat orang terpesona saat melihatnya. Dan ada juga yang menyebut Sekar Jagad sebagai peta dunia karena bentuk motif nya seperti pulau pulau.

e. Motif Batik Parang Rusak

Motif ini menggambarkan arti dari pertarungan antara manusia yang melawan kejahatan. Pertarungan yang dilakukan dengan mengendalikan diri dari segala hal buruk sehingga mereka bisa menjadi bijaksana dan mulia.

f. Batik Sido Luhur

Motif Sidoluhur umumnya dipakai oleh pegantin wanita pada saat malam pengantin. Makna dari motif ini yaitu berupa harapan agar orang yang memakai nya dapat mencapai kedudukan yang lebih tinggi sehingga dapat menjadi panutan di dalam masyarakat.

g. Motif Batik Tambal

Seperti namanya motif ini memiliki arti menambal sesuatu atau memperbaiki sesuatu yang rusak. Dan pada zaman dahulu orang percaya bahwa kain ini dapat membantu menyembuhkan orang sakit. Caranya dengan menyelimuti orang sakit tersebut dengan kain motif tambal ini.

h. Motif Batik Ceplok

Motif ini memiliki berbagai macam bentuk yang geometris. Contoh nya seperti bintang, mawar yang melingkar atau bentuk kecil kecil yang membentuk pola simetris pada kain.

i. Batik Cuwiri

Arti kata dari Cuwiri yaitu kecil kecil. Makanya motifnya pun kecil kecil. Pembuatan motif batik cuwiri menggunakan pewarna soga yang alami. Dan motif ini biasanya digunakan dalam acara mitoni orang yang hamil. Dipakai untuk kembenan atau semekan. Motif ini ditandai dengan adanya ragam hias gurda dan meru.

j. Motif Batik Keraton 
Batik Keraton merupakan cikal bakal batik batik yang ada di Indonesia. Batik ini dibuat oleh putri putri keraton dan juga para ahli pembatik yang ada di dalam keraton. Dahulu batik keraton sangatlah esklusif karena yang boleh memakai nya hanya Sultan dan keluarga nya saja. Namun saat ini batik ini sudah bebas dipakai oleh siapa saja. Batik keraton ini memiliki makna dan filosofi yang hidup.

k. Batik Loreng

Motif batik loreng mempunyai motif desain baris diagonal diantara motif parang. Pola motif ini hanya berupa garis diagonal yang sempit dan berisikan dengan pola pola kecil. Motif batik loreng juga termasuk dalam motif lama. Dan batik ini juga hanya boleh digunakna oleh keluarga kerajaan.

1. Motif Batik Semen

Salah satu batik yang biasanya digunakan untuk acara umum tidak seperti batik batik lainnya, yang digunakan untuk acara khusus atau bahkan hanya boleh digunakan oleh keluarga kerajaan saja. Motif ini terinspirasi oleh lingkungan dan keadaan alam. Hal ini dapat dilihat dari polanya yang berupa pola gunung, daun dan yang lainnya.

m. Batik Malang

Batik Malang juga terkenal akan motifnya yang cenderung cerah. Warna dasarnya adalah biru dengan ditimpa warna putih, lalu bahan itu masih ditimpa dengan warna merah. Ratarata batik Malangan ini memiliki pola ataupun simbol-simbol kota Malang, misalnya candi yang ada di kota Malang.

n. Motif Batik Pekalongan

Selanjutnya ada batik Pekalongan yang tak kalah populer. Kebanyakan motif asal Pekalongan ini akan dipengaruhi kebudayaan luar yang datang sebagai akibat dari faktor perdagangan. Hal ini karena letak kota Pekalongan yang strategis sebagai lokasi perdagangan mengingat dapat dengan mudah dicapai dari segala penjuru. Motif yang ada pada batik Pekalongan ini juga rata-rata didominasi bentuk fauna serta motif tumbuh-tumbuhan.

o. Batik Bali

Motif batik Bali banyak terinspirasi dari aneka jenis hewan seperti kura-kura, burung, bangau, dan rusa.Selain itu, motif simetris beraneka warna juga jadi ciri khas batik Bali. Salah satu yang kini sedang menjadi tren adalah batik prada yang mudah dikreasikan menjadi aneka model pakaian.

p. Batik Betawi

Pilihan warna-warna yang cerah dipadukan dengan motif unik seperti pucuk rebung, nusa kelapa, ondel-ondel, burung hong, dan gambang kromong. Kain batik Betawi sangat cocok digunakan sebagai bawahan untuk kebaya encim dengan warna-warna cerah.

q. Batik Banten

Salah satu motif batik populer dari Banten adalah motif simbut. Motif yang satu ini berbentuk mirip daun talas yang warna dan bentuknya sederhana. Batik Banten berasal dari kebudayaan Suku Baduy di kawasan pedalaman. Namun selain motif simbut, masih banyak jenis batik Banten lainnya yang tak kalah indah dari batik daerah lain.

r. Batik Madura

Madura yang merupakan daerah kepulauan memiliki ciri khas batik berwarna cerah. Nuansa pesisir digambarkan dengan pilihan warna yang menyala dan terkesan berani. Beberapa daerah di Madura yang terkenal sebagai penghasil batik antara lain Sumenep, Pamekasan, dan Tanjung Bumi.

s. Batik Kalimantan

Minat terhadap batik-batik bermotif ramai dengan kesan penuh akan terpenuhi kalau Anda memilih batik Kalimantan. Ciri khas motif batik Kalimantan didominasi oleh gambar mandau, burung enggang, dan tumbuh-tumbuhan. Sementara Kalimantan Selatan juga punya motif batik istimewa yang bernama sasirangan

t. Batik Papua

Batik Papua terkesan eksotis dengan motif-motif asimetris yang menggambarkan alam dan kebudayaan Papua. Simbol patung kayu khas Suku Asmat dan burung cendrawasih juga menjadi salah satu motif terpopuler pada batik Papua. Selain itu, ada pula motif sentani dengan bentuk alur batang kayu melingkar yang terdiri dari satu atau dua warna.

u. Batik Aceh 
Motif-motif batik Aceh terinspirasi dari kebudayaan dan cara hidup masyarakat setempat. Warna-warna yang paling sering digunakan adalah merah, kuning, dan hijau. Bentuk motifnya tidak terlalu detail dan rapat namun tetap sedap dipandang mata

v. Batik Minangkabau

Sumatera Barat memang kalah populer dengan Pulau Jawa untuk urusan batik. Tetapi kualitas dan keindahan batik Minangkabau tak perlu diragukan lagi. Batik Minangkabau juga dikenal dengan sebutan batik tanah liek (tanah liat). Karena tanah liat merupakan salah satu bahan dasar yang digunakan dalam proses pembuatan batik. Aneka motif khas batik Minangkabau antara lain motif geometrik, pucuk rebung, gambaran kebudayaan Minangkabau, dan siku-siku baragi.

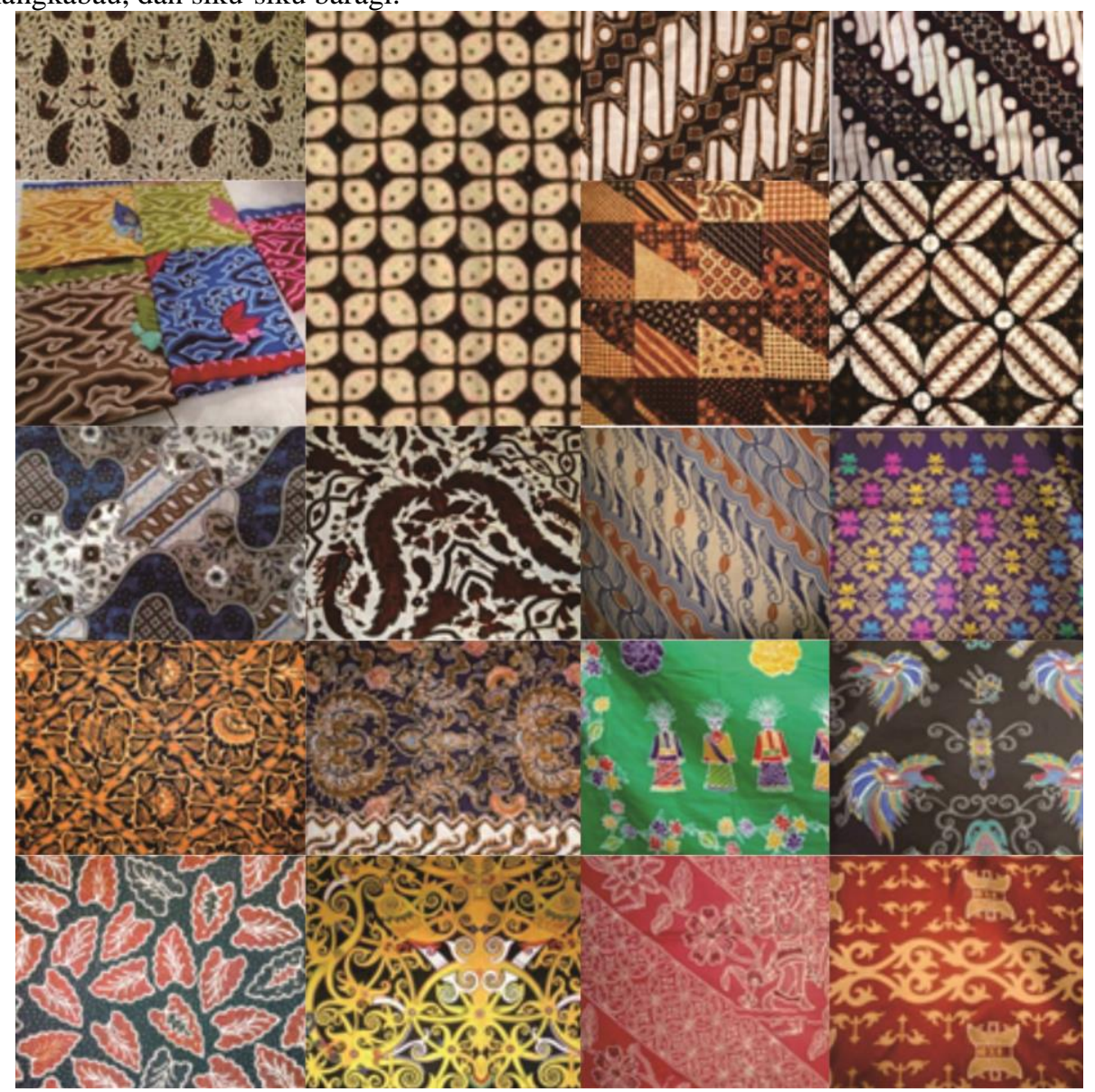

Gambar 11 Berbagai macam motif batik.

\section{BAHAN DAN MATERIAL INTERIOR}

Menurut Kamus Besar Bahasa Indonesia (KBBI), bahan adalah 1 barang yang akan dibuat menjadi satu benda tertentu; bakal; 2 (segala) sesuatu yang dapat dipakai atau diperlukan untuk tujuan tertentu, seperti untuk pedoman atau pegangan, untuk mengajar, memberi ceramah; 3 sesuatu yang menjadi sebab (pangkal) atau sikap (perbuatan): -- tertawaan; -- pertikaian (perselisihan); 4 barang yang akan dipakai untuk bukti (keterangan, alasan, dan sebagainya). Dalam konteks penelitian ini, bahan yang dimaksud adalah barang yang akan dibuat menjadi satu benda tertentu. Sedangkan material adalah bahan yang akan dipakai untuk membuat barang lain; bahan mentah untuk bangunan. cutting adalah:

Bahan dan material yang digunakan sebagai pembentuk interior dengan sistem laser

a. Plat besi baja: Jenis plat baja ini biasanya banyak digunakan sebagai bahan material pembangunan konstruksi karena plat baja memiliki kekuatan yang sudah tidak diragukan 
lagi. Biasanya plat baja ini digunakan sebagai material penyambung struktur profil konstruksi bangunan. Tebal lembaran besi ini adalah 1.2-100mm.

b. Plat besi alumunium: Plat aluminium adalah lembaran plat atau pelat logam yang ringan dan kuat. Plat aluminium memiliki sifat anti karat, tidak mudah terbakar dan tahan terhadap segala jenis cuaca. Plat jenis ini sendiri mudah dibentuk, sehingg banyak digunakan dalam bidang industri seperti dalam kebutuhan advertising. Ketebalan plat besi alumunium di pasaran adalah $0.22-0.7 \mathrm{~mm}$.

c. Plat Stainless Steel: Banyak kelebihan yang dimiliki dari plat berbahan stainless steel ini salah satunya adalah memiliki daya tahan karat yang cukup tinggi. Dan banyak produsen industri yang melakukan kombinasi atau finishing untuk menambah atau menghasilkan kualitas stainless steel yang lebih baik. Ketebalan plat stainles di pasaran adalah $0.4-10 \mathrm{~mm}$.

d. Tembaga: Tembaga adalah suatu unsur kimia dalam tabel periodik yang memiliki lambang $\mathrm{Cu}$ dan nomor atom 29. Lambangnya berasal dari bahasa Latin Cuprum.Tembaga merupakan konduktor panas dan listrik yang baik. Selain itu unsur ini memiliki korosi yang cepat sekali. Tembaga murni sifatnya halus dan lunak, dengan permukaan berwarna jingga kemerahan. Tembaga dicampurkan dengan timah untuk membuat perunggu. Secara umum ketebalan kuningan yang ada di pasaran adalah 0.5, 0.8, 1, 1.5, 1.8, 2, 2.5, 3, 4, 5 mm.

e. Kuningan: Kuningan adalah paduan logam tembaga dan logam seng dengan kadar tembaga antara 60-96\% massa. Tembaga dalam kuningan membuat kuningan bersifat antiseptik, melewati efek oligodinamis. Contohnya, gagang pintu yang terbuat dari kuningan dapat mendisinfeksi diri dari banyak bakteri dalam waktu 8 jam. Secara umum ketebalan kuningan yang ada di pasaran adalah $0.5,0.8,1,1.5,1.8,2,2.5,3,4,5 \mathrm{~mm}$.

f. MDF: Medium Density Board (MDF) dibuat untuk menutupi beberapa kelemahan plywood yang permukaannya kurang halus, mudah retak dan pecah pada ukuran lebar yang terlalu kecil dan hasil potongan yang kasar. Pada umumnya, tebal MDF adalah $9 \mathrm{~mm}, 15 \mathrm{~mm}$ dan $18 \mathrm{~mm}$.

g. Akrilik: Akrilik merupakan plastik yang bentuknya menyerupai kaca. Namun, akrilik ternyata mempunyai sifat-sifat yang membuatnya lebih unggul dibandingkan dengan kaca. Salah satu perbedaanya adalah kelenturan yang dimiliki oleh akrilik. Akrilik merupakan bahan yang tidak mudah pecah, ringan, dan juga mudah untuk dipotong, dikikir, dibor, dihaluskan, dikilapkan atau dicat. Akrilik dapat dibentuk secara thermal menjadi berbagai macam bentuk yang rumit. Ukuran akrilik yang biasa digunakan adalah 1.5, 2, 3, 5, 8, 10, $15 \mathrm{~mm}$. Warna yang tersedia adalah warna bening dan warna solid.

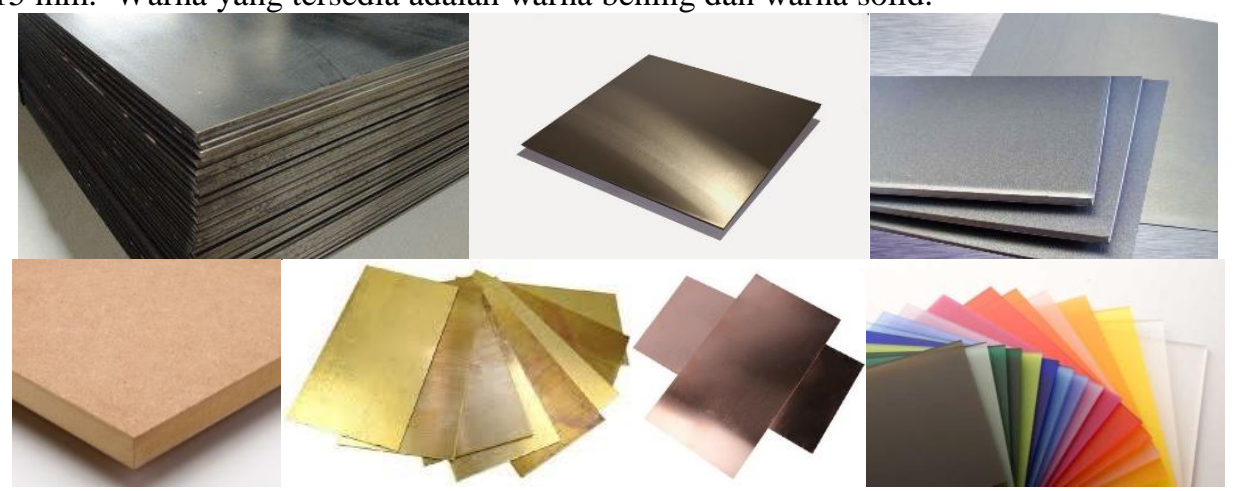

Gambar 2. Berbagai macam bahan dan material.

Selain bahan di atas, terdapat material lain yang bisa digunakan yaitu kayu/bamboo, kain, kertas/karton, karet stempel, kaca (grafir) dan lembaran kulit.

\section{TEKNOLOGI PERENCANAAN}

Teknologi di bidang perencanaan sangat berkembang pesat. Dahulu, proses menggambar dilakukan secara manual. Tingkat presisi akan dimiliki oleh orang dengan skil yang tinggi dan jumlahnya tidak banyak. Saat ini proses perencanaan sudah dilakukan dengan system computerized. Komputer terdiri dari dua bagian yaitu :

a. Perangkat keras

- Pemroses atau CPU sebagai unit pengolah data 
- Memori RAM, tempat penyimpanan data sementara

- Hard drive, media penyimpanan data semi permanen

- Perangkat masukan, media yang digunakan untuk memasukkan data untuk diproses oleh CPU, seperti mouse, keyboard, dan tablet

- Perangkat keluaran, media yang digunakan untuk menampilkan hasil keluaran pemrosesan CPU, seperti monitor, speaker, headset, plotter, proyektor, dan printer

b. Perangkat lunak

- Sistem operasi

- Program dasar pada komputer yang menghubungkan pengguna dengan hardware komputer. Sistem operasi yang biasa digunakan adalah Linux, Windows, dan Mac OS. Tugas sistem operasi termasuk (namun tidak hanya) mengatur eksekusi program di atasnya, koordinasi input, output, pemrosesan, memori, serta instalasi software.

- Program komputer

- Merupakan aplikasi tambahan yang dipasang sesuai dengan sistem operasinya

\section{TEKNOLOGI PELAKSANAAN}

Teknologi terus berkembang untuk semakin memudahkan dalam proses pelaksaan/produksi. Seni ukir saat ini dapat dilakukan dengan mesin. Hasil akan sangat tergantung dari hasil perencanaan berupa file gambar yang sudah dibuat dengan software tertentu di computer. Mesin ini biasa disebut dengan mesin laser cutting. Disebut demikian karena proses pemotongan menggunakan laser dengan suhu tertentu sehingga dapat memeotong material yang diinginkan.

Cara kerja mesin ini adalah dengan sistem computerized. File gambar yang sudah ada di olah dan diterjemahkan dalam gerakan membentuk pola yang sudah dibuat disertai dengan laser pemotongnya. Semakin keras material, maka akan semakin lama proses pemotongannya. Bidang maksimum yang bisa dipotong juga beragam, dimulai dari $60 \mathrm{~cm}$ x $50 \mathrm{~cm}$ sampai 2 meter lebih.
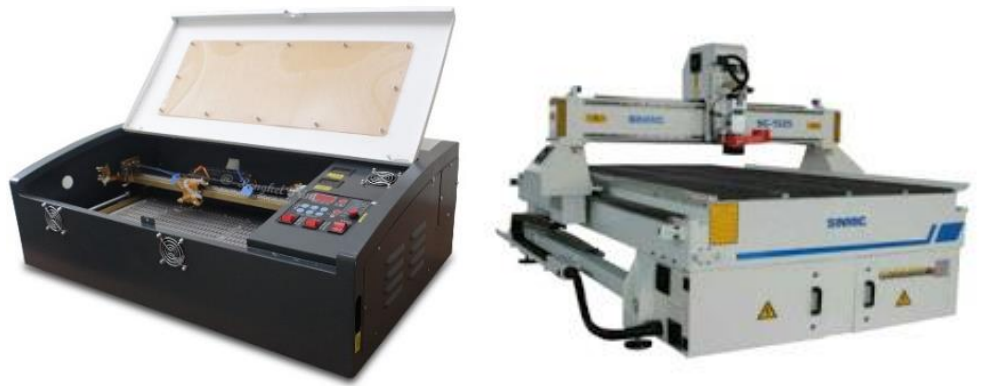

Gambar 12 Berbagai alat mesin laser cutting. 


\section{METODE}

Metode yang dilakukan pada penelitian ini adalah metode kualitatif, dengan model studi kepustakaan, khususnya mencari referensi tentang batik dan teknologi komputer. Selanjutnya membuat analisa terkait penerapan motif batik pada desain interior. Studi kasus dibuat untuk contoh permodelan.

\section{Tahapan Pekerjaan}

Dalam mendesain, pasti akan diawali dengan tahap perencanaan. Tahap perencanaan diawali dengan menbuat bagan alir pekerjaan.

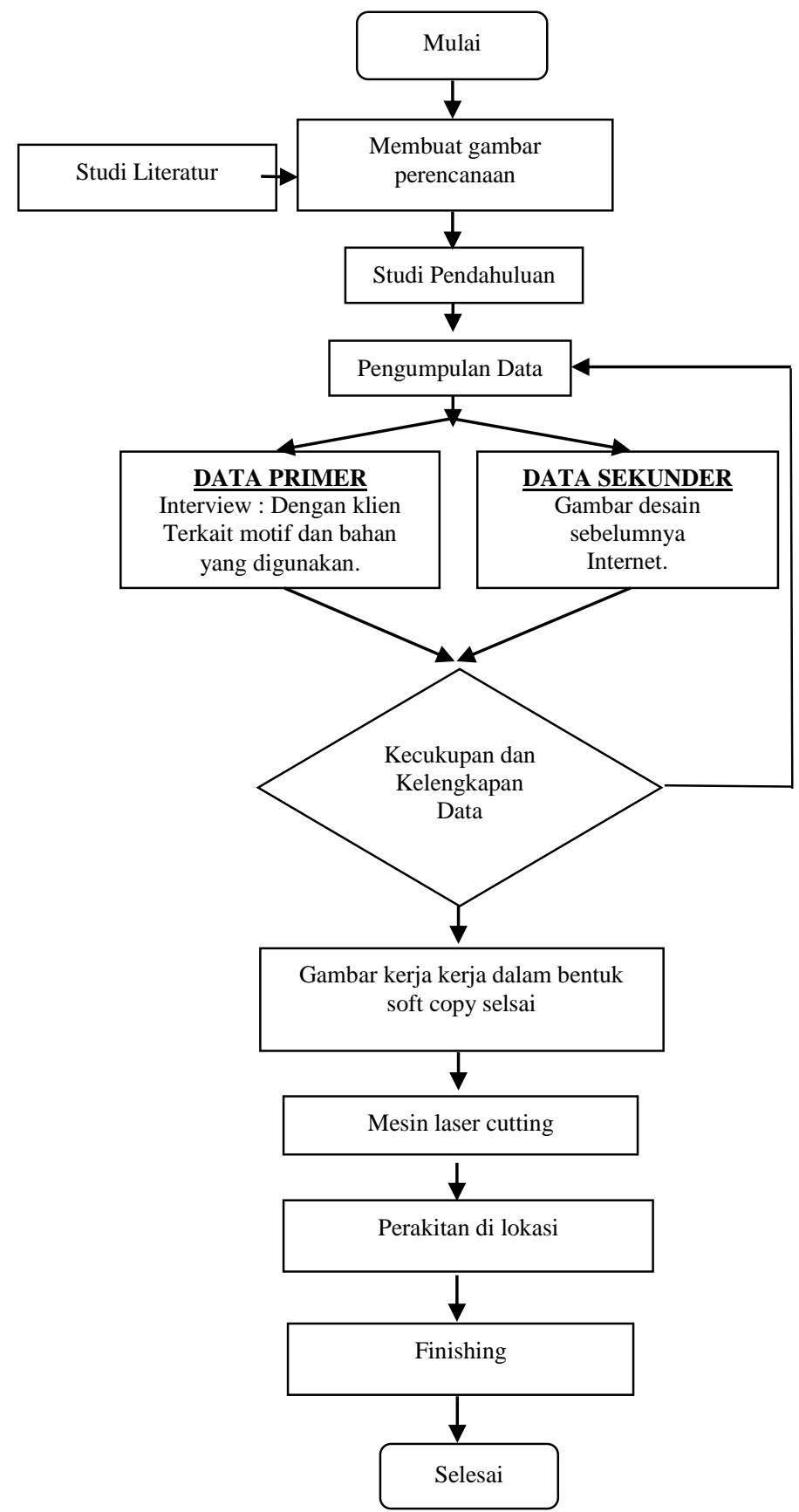

Gambar 13 Bagan Alur Penelitian 
- Tahap membuat gambar perencanaan diawali dengan studi pendahuluan. Studi pendahuluan merupakan proses pengumpulan data sebelum membuat desain. Pengumpulan data berupa interview dengan klien terkait motif yang kana dibuat, material, serta dipadukan dengan data sekunder yang sudah ada, yaitu gambar-gambar desain yang sudah ada ataupun dari internet.

- Setelah data lengkap, berikutnya membuat gambar kerja menggunakan software dikomputer. Ukuran harus sudah disesuaikan dengan ukuran yang direncanakan karena hasil pemotongan akan sangat dipengaruhi gambar di computer.

- Setelah gambar sudah selesai, berikutnya adalah mengirimkan data ini pada mesin laser cutting untuk proses pemotongan. Sesuaikan jenis bahan yang digunakan dalam proses pemotongan.

- Setelah bahan selesai dipotong, berikutnya adalah tahap finishing dan pemasangan.

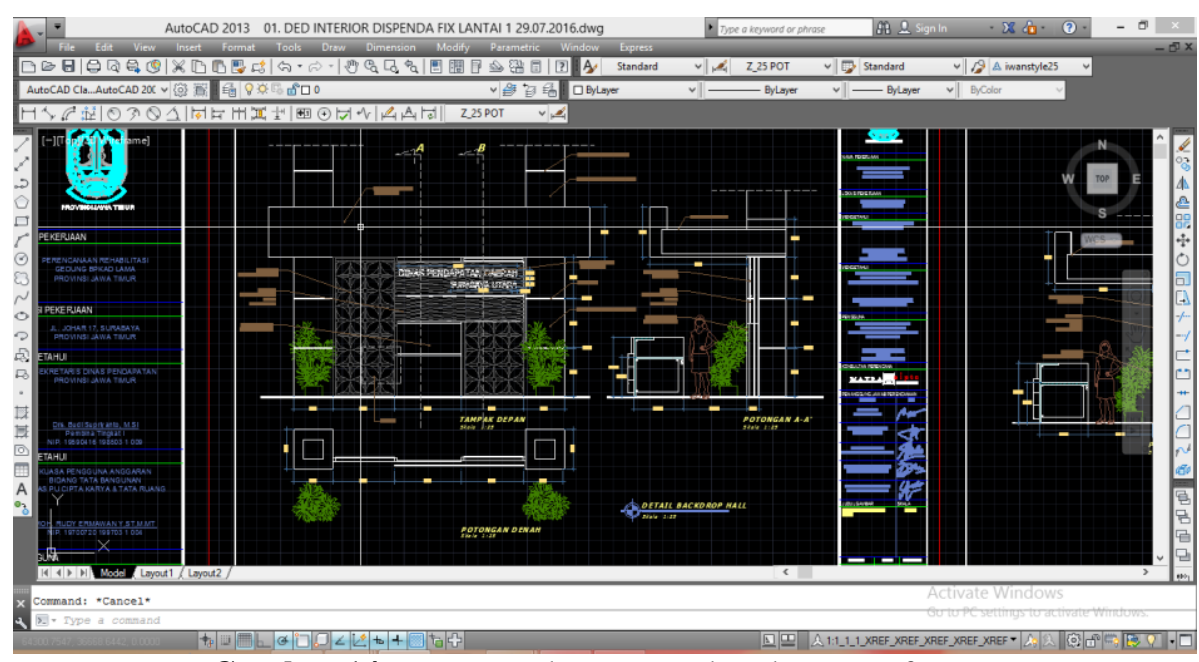

Gambar 14 Proses pembuatan gambar dengan software.

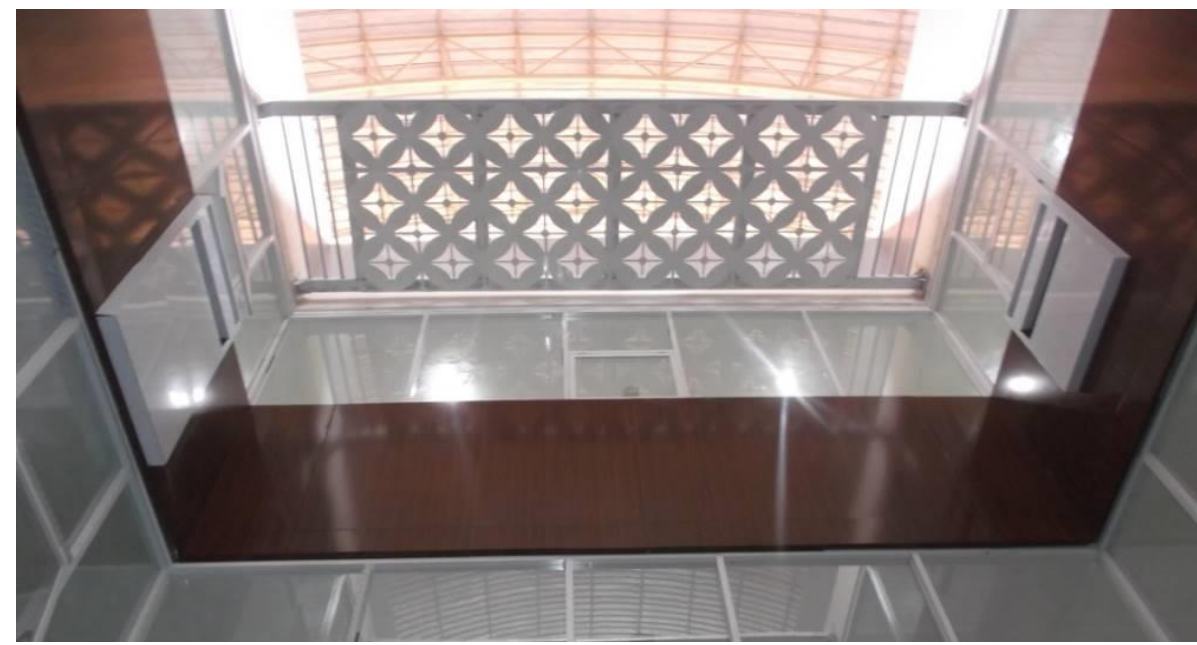

Gambar 15 Hasil pemasangan plafon motif batik kawung. 


\section{APLIKASI MOTIF BATIK PADA INTERIOR}

Dalam desain interior, ada empat elemen yang akan didesain, yaitu elemen lantai, elemen dinding, elemen plafon, serta elemen perabot. Motif Batik dapat dimasukkan dalam tiga elemen, yaitu dinding, plafond dan perabot. Untuk pembuatan motif lantai akan sangat jarang menggunakan mesin laser cutting, karena motif lantai sudah dibuat secara khusus.

\section{Dinding}

Pada area dinding, motif batik dapat diaplikasikan pada dinding utama (berupa dinding bata)+backdrop dan dinding partisi portable. Bahan yang digunakan bisa berupa cutting bahan metal seperti kuningan dan stainless, kaca, akrilik serta bahan MDF yang sudah difinishing. Motif batik yang dipilih juga dapat disesuaikan konsep dalam ruangan. Untuk finishing warna yang digunakan untuk bahan metal, kaca dan akrilik adalah warna expose/warna aslinya, sedangkan warna untuk MDF disesuaikan konsep dalam ruang.

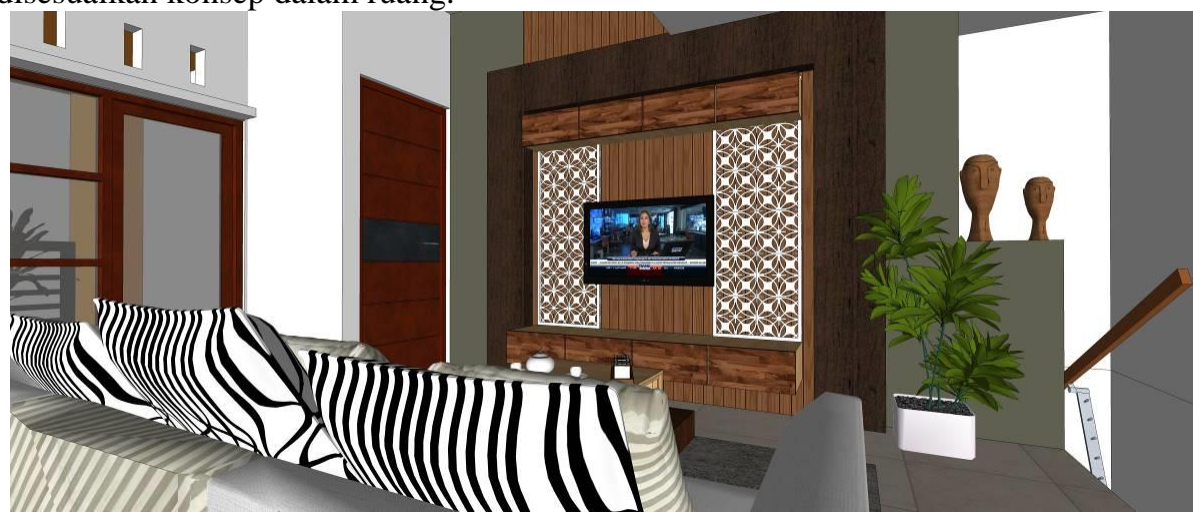

Gambar 16 Hasil permodelan motif batik kawung pada dinding.

Plafon

Pada area plafon, motif batik dapat diaplikasikan pada keseluruhan bidang atau sebagian bidang plafon. Jika menggunakan sebagian, motif batik bisa diletakkan di area tengah atau sisi plafon. Bahan yang digunakan bisa berupa cutting bahan metal seperti kuningan dan stainless, atau bahan MDF yang sudah difinishing. Motif batik yang dipilih juga dapat disesuaikan konsep dalam ruangan. Untuk warna yang digunakan untuk bahan metal dapat warna expose, sedangkan untuk MDF disesuaikan konsep dalam ruang.

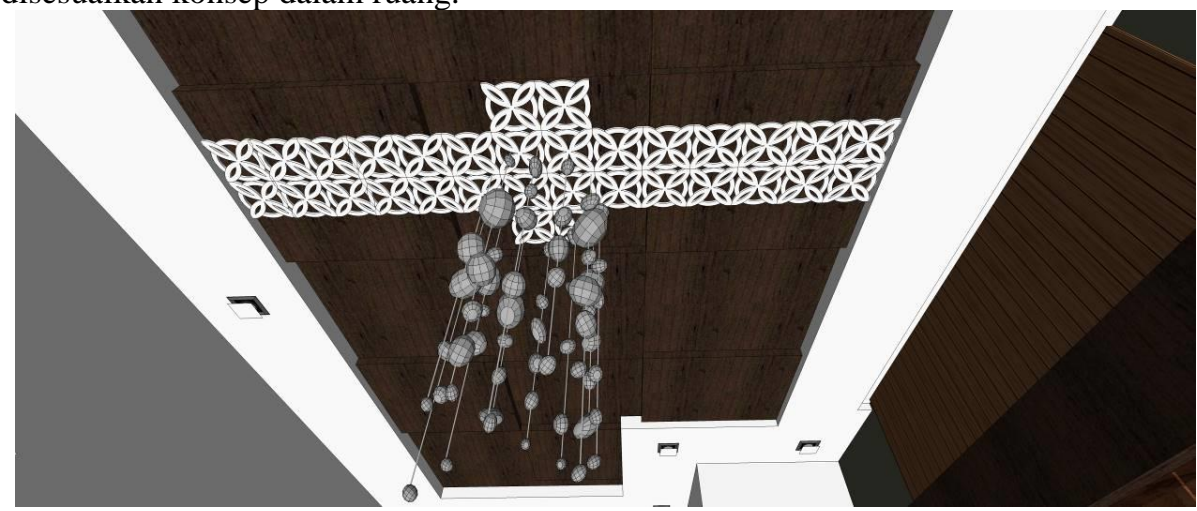

Gambar 17 Hasil permodelan motif batik kawung pada plafon.

Perabot

Pada perabot, motif batik dapat diaplikasikan pada keseluruhan bidang atau sebagian bidang perabot. Jika menggunakan sebagian, motif batik bisa diletakkan di area tengah atau sisi bidang perabot. Bahan yang digunakan bisa berupa cutting bahan metal seperti kuningan dan stainless, akrilik serta bahan MDF yang sudah difinishing. Motif batik yang dipilih juga dapat disesuaikan konsep dalam ruangan. Untuk finishing warna yang digunakan untuk bahan metal dan akrilik adalah warna expose/warna aslinya, sedangkan warna untuk MDF disesuaikan konsep dalam ruang. Pada perabot tertentu, material kain dan kulit juga bisa diaplikasikan. 

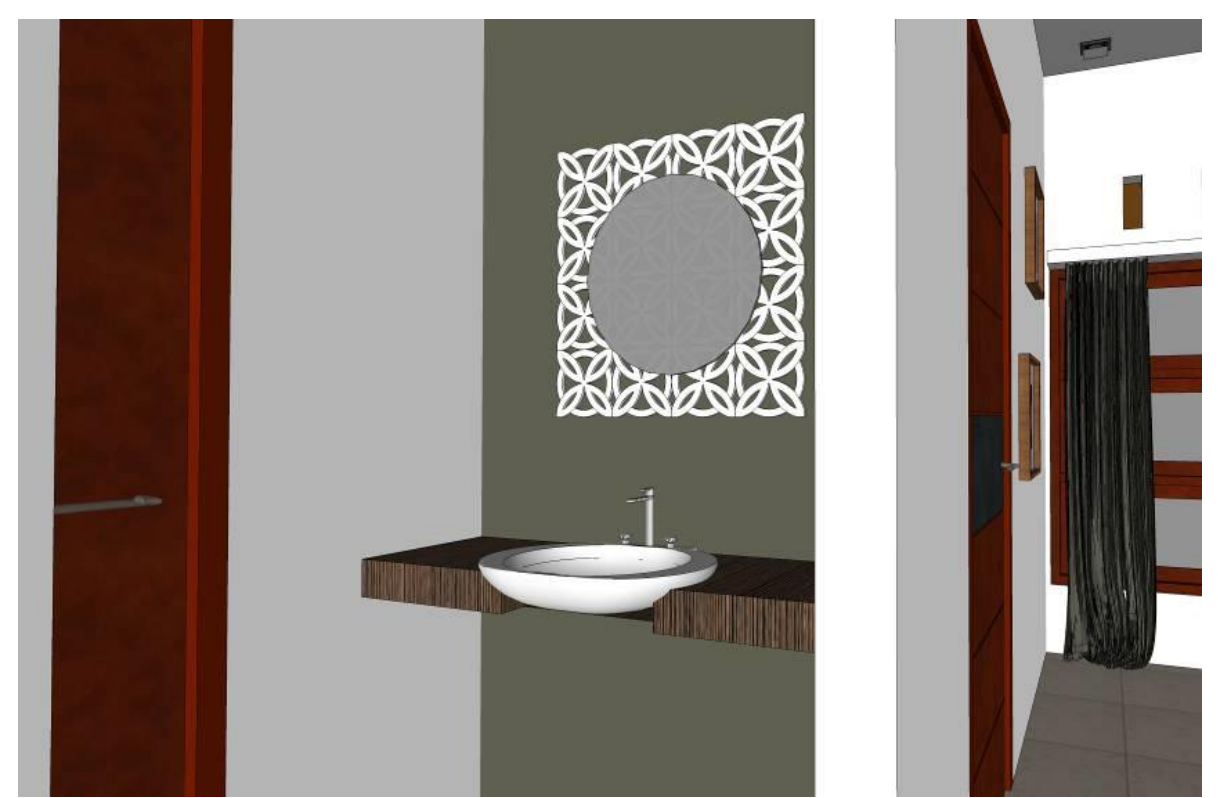

Gambar 18 Hasil permodelan motif batik kawung pada perabot.

Tabel 1 Aplikasi dan Finishing Motif batik pada Elemen Interior

\begin{tabular}{|c|c|c|c|c|}
\hline NO & $\begin{array}{c}\text { ELEMEN } \\
\text { INTERIOR }\end{array}$ & MATERIAL & FINISHING & PERLETAKAN \\
\hline 1. & Dinding & $\begin{array}{l}\text { Lembaran besi } \\
\text { Kuningan } \\
\text { Tembaga } \\
\text { Stainles } \\
\text { Akrilik } \\
\text { MDF } \\
\text { Kaca (grafir) }\end{array}$ & $\begin{array}{l}\text { Exposed untuk bahan } \\
\text { metal dan acrylic } \\
\text { MDF dengan cat duco }\end{array}$ & $\begin{array}{l}\text { Backdrop } \\
\text { Dinding Portable }\end{array}$ \\
\hline 2. & Plafon & $\begin{array}{l}\text { Lembaran besi } \\
\text { Kuningan } \\
\text { Tembaga } \\
\text { Stainles } \\
\text { Akrilik } \\
\text { MDF } \\
\text { kayu }\end{array}$ & $\begin{array}{l}\text { Exposed untuk bahan } \\
\text { metal dan acrylic } \\
\text { MDF dengan cat duco }\end{array}$ & Plafon \\
\hline 3. & Perabot & $\begin{array}{l}\text { Lembaran besi } \\
\text { Kuningan } \\
\text { Tembaga } \\
\text { Stainles } \\
\text { Akrilik } \\
\text { MDF } \\
\text { Kayu } \\
\text { Kain } \\
\text { kulit } \\
\end{array}$ & $\begin{array}{l}\text { Exposed untuk bahan } \\
\text { metal dan acrylic } \\
\text { MDF dengan cat duco } \\
\text { Kayu, kain dan kulit } \\
\text { dengan bahan khusus }\end{array}$ & $\begin{array}{l}\text { Elemen desain } \\
\text { pada meja, kursi, } \\
\text { cermin, dll }\end{array}$ \\
\hline
\end{tabular}




\section{KESIMPULAN}

Motif batik adalah karya warisan budaya yang harus terus dilestarikan. Dengan perkembangan jaman dan teknologi, karya batik harus dapat berkembang sejalan dengan kemajuan yang ada tanpa merubah ruh dari batik itu sendiri. Kemajuan teknologi dalam dunia interior terus berkembang baik dari segi metode perencanaan maupun teknik pelaksanaannya. Kesimpulan dari penelitian ini adalah:

1. Reaktualisasi motif batik dapat dilakukan sejalan dengan perkembangan teknologi dari segi metode perencanaan dan teknis pelaksanaan

2. Metode perencanaan berkembang dengan penggunaan software khusus pada computer

3. Teknik pelaksanaan dikembangakan dengan menggunakan alat khusus yaitu mesin laser cutting

4. Bahan dan material disesuaikan dengan konsep dan gaya interior yang diinginkan

5. Aplikasi motif batik dengan mesin laser cutting dapat diaplikasikan pada elemen interior berupa dinding, plafon dan perabot.

\section{DAFTAR PUSTAKA}

Wulandari, Ari. 2011. Makna Filosofis, Cara pembuatan, dan Indutri Batik. Andi Publisher

Kusrianto, Adi. 2014. Batik, Filosofi, Motif dan Kegunaannya. Yogyakarta: Andi

Hartono, Jogiyanto. 2000. Pengenalan Komputer: Dasar Ilmu komputer, Pemrograman, Sistem Informasi, dan Intelegensi Buatan. Yogyakarta: Andi

https://www.arsitag.com/article/mengenal-akrilik 